Published in Svallfors, Stefan and Peter Taylor-Gooby (eds) "The End of the Welfare State? Public Attitudes to State Retrenchment". 1999. Routledge, 235-264

\title{
10. AND WHAT IF THE STATE FADES AWAY? THE CIVILISING PROCESS AND THE STATE ${ }^{12}$ \\ Zsuzsa Ferge
}

By ...declaring government intervention the ultimate evil, laissez-faire ideology has effectively banished income and wealth redistribution. ...Wealth does accumulate in the hands of its owners, and if there is no mechanism for redistribution, the inequities can become intolerable. George Soros

The armour of civilised conduct would crumble very rapidly if, through a change in society, the degree of insecurity that existed earlier were to break in upon us again, and if danger became as incalculable as it once was. Corresponding fears would burst the limits set to them today. Norbert Elias

A distinguishing characteristic of the European variant of capitalism lies in the role played by the state. Governments are expected to intervene in the free play of market forces not only to provide a safe environment for capital but also to protect the interests of citizens and particularly of minorities who are unsuccessful in a free market. The latter is achieved through employment regulation, social security, health care and equal opportunities, in fact the whole panoply of measures and policies which make up the modern welfare state.

-State welfare has achieved its most developed form in western Europe. Now - after the collapse of "state socialism" and the strengthening of globalisation -

\footnotetext{
${ }^{1}$ The underlying research was supported by a grant of the Hungarian Research Fund (OTKA) (grant no.T 026067 )

${ }^{2}$ I wish to thank the Institute of Human Studies in Vienna. Six months of visiting fellowship there enabled me to start the research the first, yet tentative results of which are summed up in the present paper. I have to thank also all those who made comments on former drafts: Shlomo Avineri, Herbert Gans, Don Kalb, Károly Kecskeméti, S.M. Miller, Pál Léderer, Frances Fox Piven, Agnes Simonyi, Adrian Sinfield, Stefan Svallfors, Abram de Swaan, Peter Taylor-Gooby, and the doctoral students in Budapest. While most of their criticisms were justified, I ask to be excused if some of their comments had not been given due attention at this point.
} 
democratic welfare capitalism is increasingly under threat from the more liberal variant of capitalism as it has developed in the United States. The 'minimal state" is high on the agenda of the globalists, but this objective is highly questionable.

This chapter takes a step back from the analysis of contemporary attitude data to consider the development of modern society. It relies on Elias' analysis of The Civilizing Process (1982). The object is to identify what the core values of European civilisation are and what role the state plays in sustaining them. This provides the basis for an understanding of what Europe - East and West will lose, if it is the liberal market variant of capitalism that becomes dominant in this sub-region of the world system. This is what is at stake in the debate about state retrenchment.

\section{What is meant by civilisation?}

Civilisation has many different meanings, and may be interpreted in a relatively neutral, or a strongly value-loaded way. So let me start by summarising - without giving any definition - what I mean and what I do not mean by the concept ${ }^{3}$.

The sense in which I use the concept originates in the work of Norbert Elias and of those who have followed up his work (de Swaan in the first place). In their sense civilisation applies essentially to the processes having taken place in Western Europe from about the $15^{\text {th }}$ or $16^{\text {th }}$ century on, accompanying the development of capitalism, technical modernisation, urbanisation, and basic socio-political changes in the fabric of society. The civilising process described by Elias encompasses changes from the most common-place behaviours to elaborate standards, norms, forms of communication. It affects mental functions, morals and sensibilities, the whole affective household. The second half at least of the above period coincides with the well-known process of individualisation. It has been hence accompanied by the changing role of the family and by the increasing need of the individual for privacy (Ariès and Duby, 1987). The altering economic and political circumstances have been accompanied also by changes in interpersonal relationships such as the decrease of social distances between groups of different rank, then between genders, generations, 'superiors' and 'inferiors' within organisations, and between governments and their subjects (Swaan 1990: 150-151 ). The core element of the whole process is probably the pacification of everyday life which has become possible when the state had monopolised violence. This step has freed man from the constant fear of being attacked by others, and the constant necessity of being alert for a counterattack.

\footnotetext{
${ }^{3}$ While my starting point was the work of Elias, de Swaan and the Amsterdam School building on the work of Elias, I would agree with them if they disagreed with me because I do not follow exactly the original interpretations.
} 
It is suggested by the theory that attitudes transmitted through generations end up by being built into the personality, leading to 'the formation of a more complex and secure "super-ego" agency' (Elias 1982:248) ${ }^{4}$ replacing outside by inside constraints. The most frequently mentioned 'civilised' personality traits are, in Elias' work, increasing 'self-restraint in some or in all respects; a more firmly regulated behaviour .. which is bound up with greater foresight, ... a greater refinement of manners and which is studded with more elaborate taboos' (Elias and Scotson 1994:152), and the submission of sudden impulses to the requirements of a more long-term view.

I would like to add to this inventory a few considerations. Some of them just underscore elements included in the above approach. Some may complete it in ways which may or may not coincide with the line of thought of Elias. My intention is not to criticise or to appraise the oeuvre of Elias. I just build upon it and use it as a means to get closer to the problem I grapple with, the impact of the withdrawal of the state from some of its former functions upon human coexistence in complex, modern societies.

First, what is most essential for me is that civilisation is about social coexistence: how to live together in a society. In that sense, all relatively durable societies ${ }^{5}$ have 'worked out' a civilisation ${ }^{6}$, consisting of many elements from codes of behaviour and communication to moral norms, and to instruments of coercion to enforce these codes and norms. Society recognises itself through these codes and norms. This implies that 'civilisation' is very closely connected to social integration on the one hand, and to the formation of social identities on the other. From this perspective it is clearly ill-advised

\footnotetext{
${ }^{4}$ The very idea of civilisation as a process of imposing self-control goes back of course to Freud as widely acknowledged by Elias and Swaan. The super-ego is not only an individual phenomenon - it is one of the connecting links to society. Freud explicitly says that some curtailment of individual freedom seems to be the price of civilisation: "The liberty of the individual is not a benefit of culture. It was greatest before any culture, though indeed it had little value at that time, because the individual was hardly in a position to defend it. Liberty has undergone restrictions through the evolution of civilisation, and justice demands that these restrictions should apply to all' (1951: 59-60). It seems to me that it is just the 'necessary' or 'acceptable' degree of curtailment of individual freedom which lies at the heart of the current debates about the role of the state.

${ }^{5}$ 'Civilization becomes possible when a well established agriculture and technology give rise to an economic surplus enabling the development of cities and a written culture'. (New Encyclopaedia Britannica, vol.23.)

${ }^{6}$ Or culture. I do not want to go into definitional problems, all the less, because there is a certain chaos even in the most 'scientific' literature. Encyclopedias, among others The Columbia Encyclopedia (1993), or The New Encyclopaedia Britannica, Macropaidea (1983) use these concepts (culture, civilization, modernisation) almost cross-definitionally. According to the New Encyclopedia for instance, with the advance of modernisation 'at any rate, the outcome will be a new world of civilization, heir to Western and non-Western cultures alike'.The different meaning of the concepts in different languages further complicates the issue as witnessed by the analysis of Elias on the French and German use of the term, or by the title of the seminal essay of Freud which is 'Das Unbehagen in der Kultur' in German, and 'Civilisation and its discontents' in English.
} 
to make value judgements about civilisations. It is impossible to decide whether the Peruvian, the Chinese or the modern West-European civilisation is 'better' or 'more developed'.

Second, in the hierarchically organised societies analysed by Elias the values, codes, norms, elements of 'culture' which ultimately become the general social norms seem to evolve in the upper, most powerful strata. It should be repeatedly emphasised that the upper strata are not absolutely autonomous in this 'travail'. The interaction among the various parts of society has probably always had an impact on the end-products - even though we do not know enough about these interactions and mutual influences. Because of the relations of domination, though, the results appear usually indeed as the product of the higher strata. (The recently emerging pervasive and apparent domination of the so-called 'mass culture' would require either a different explanation, or, rather, a more complex elaboration of the above explanation.)

Third, it is suggested in the work of Elias that the civilising process has 'happened' by and large spontaneously among the upper classes he is mostly concerned with. It is not analysed in detail how the process has spread through society so as to 'colonize socially inferior outsider groups' (Fletcher 1997:42), or to yield 'we-identities' in larger communities. Hence one may gather the impression from his work that if the civilising process has affected larger segments of society, this has happened mainly through a slow trickling down process. However, the idea of a spontaneously trickling down stream is probably misleading. The elements of civilisation accepted by those at the top (and presented as their own product) have always been conditioned by their own circumstances and relationships. Since these conditions of the 'bottom', or of all the milieus below the top have been different from those on the top, the process of adaptation was probably not very easy. The 'lower' strata may not have been well prepared - materially as well as spiritually - to adopt the new 'habitus'. The examples to illustrate this point may be very trivial indeed. If 'civilised' manners required the use of forks, knives and spoons, one had to be able to get (to buy or to fabricate) those instrument. One also had to become convinced that the non-utilisation of these instruments puts one among the less-well civilised, ultimately among the barbarians, who do not really belong to the given society. In other words, there may or may not have existed a fit between the new habitus emerging at the top and the conditions of the 'others'. Habitus as the logic or sense of practice (sense pratique) is the precondition of practices which are in line with the requirements of the given conditions (Bourdieu 1972). It can function 'adequately' if the social actor possesses 'the minimum economic and cultural capital necessary actually to perceive and seize' the requirements of the given situation (Bourdieu and Wacquant 1992:124). And these capacities and dispositions which help to cope or to follow 'adequate' or 'rational' practices, or just to behave adequately in any given situation (applying for the most modest job, negotiating with public agencies about backward payment of bills, and so forth) have to be acquired somehow. But because of the conditions and the 
capitals shaping the 'adequate' habitus on the top are so far apart from those at the bottom, the automatic trickling down or imitation may in many cases be impossible.

Fourth, another reading of the above problem suggests that the elements of civilisation are the products of a 'travail' using resources, and they themselves are resources. In unequal societies the resources and the access to resources (for instance literacy and the access to literacy) are unequally distributed. I am unwilling and unable to judge whether the civilisation process makes people and societies better or worse. I suggest, though, that being 'more' civilised within any given society is (more often than not) an advantage. It means, among other things, that one knows better the 'rules of the game', that one is better prepared to live according to the accepted dominant norms of this society, and hence to exploit the opportunities offered by it, to cope with its reality and to adjust to its changing realities. If this is true, then one aspect of the process may indeed be assessed in value terms. If being 'more civilised' helps to survive in a given society, then it is a crucial question to what extent does the civilising process reach all the members of this society. Those who are not reached by the major elements of the civilising process, or those who are left with a thin 'coating', or left out altogether, have little chance to succeed in the given society, whatever the stakes of success are. The components of the civilising process are indeed constituent parts of the social or cultural capital. If they are unequally spread, the inequalities in physical and social life chances may become very great ${ }^{7}$. If things are just left to themselves, the gaps between the expected 'civilised', and the real behaviour will usually increase, and may become a source of tensions, of social exclusion, and so forth. My conclusion from this is that either some minimum capital has to be made accessible, or some efforts should be exerted to shape the conditions so as to bridge, at least to some extent, the above gaps.

Fifth, just because of the absence of a spontaneous trickling down process, and the interests of those at the top to 'spread' at least some elements of civilisation, there have always been different civilising agents. In Europe for instance Churches and schools have always endorsed a civilising mission (i.e. of spreading codes, norms, etc.). They have been joined in modern or modernising Europe by other institutions, for instance by old and new fraternities and associations, particularly trade unions (Kalb 1997), by factories, but also by the army or the police. Perhaps the first great attempt to build a civilising 'milieu' around production was New Lanark as conceived by Robert Owen at the end of the eighteenth century. (The village built for the workers included all the civilising institutions known at the time including dance classes for the daughters of the workers, selfdisciplining devises built into the production process, rules for buying

\footnotetext{
${ }^{7}$ The same 'rule' may not apply to groups or societies (nation-states) on various levels of civilisation if they get into conflict with each other. Less civilised, hence more violent units may easily overpower the other party -- at least on the short run.
} 
grocery using limited credit, and so forth. The only institution banned from the scene was the pub.) The civilising functions of the firm gained momentum from the middle of the nineteenth century in England (an example being the small town of Saltaire near Bradford, built by the industrialist Sir Rufus Salt), and spread all over Europe (for the Netherlands, see Kalb, 1997). Much more research seems to be needed to understand the impact of, and the competition between the various civilising agents.

Sixth, the norms, codes etc. which have been spread (or probably more often than not enforced) throughout society may not have covered everything understood as 'civilisation'. The agenda of the civilising agents may not have been very clear, but probably those elements were prominent on it which were deemed by the more powerful as 'necessary' for everybody. Hence it may well be that -- because in unequal societies the top has by definition more resources than the bottom, because the specialists of the symbolic tend to be closer to the top than to the bottom, and because of the will to retain significant distinctions had always been strong -- the top have retained, or developed later, more, and more intricate, more refined patterns than those 'forced down' on society at large.

Seventh, the above considerations already suggest that the civilising process was never smooth. It may have coincided with the interests of those 'to be civilised', and then some of its elements may have been assimilated or imitated spontaneously. More often than not, though, some form of coercion had to be used to enforce the new or different codes, norms, etc. The history of the civilisation process must be therefore written also as the history of the resistance against, or the fight with, the civilising agents. (This is also part of the story of the interaction between the various parts of society mentioned above.)

Eighth, Elias was essentially concerned with the control and monopolisation of physical violence. It seems to me though that -- at least in the European civilisation process -- a crucial thread is the change in the respective role and weight of physical and symbolic violence. For a long time many agents had been able to rely mainly upon real (physical) violence, or to combine symbolic and physical coercion. In the schools of traditional societies the main educational goals (which may have belonged either to the open, or to the hidden agenda) were obedience and submission to authority. In order to achieve these goals, the most cruel methods of physical punishment and of mental pressure were widely accepted. In some of the modern civilising agencies, the police for instance, physical violence has retained much of its role for long.

The assimilation of norms, or the strengthening of the 'super-ego' is seen as successful when outside constraints are replaced by inside ones. It is doubtful, though, whether physical violence can successfully promote this process, 
whether indeed our social 'nature' may be changed by sheer physical coercion. If not, then a shift from physical to symbolic constraints may enhance the efficacy of the whole process. As a matter of fact, the legitimacy of physical violence has been questioned in the last decades even in institutions where it had been seen for long as legitimate -- from the family through schools to the police ${ }^{8}$. (Whether the open and even punishable repudiation of physical violence has indeed been implemented in the various institution is subject to doubt, or at least it depends on the public control of the operation of the given institution.) The shift from open to subtle violence may have had different reasons, and may have been rationalised altogether differently from that suggested above. In any case, symbolic violence has had to become so effective as to be able to disguise its real nature, to become soft violence, to make forget that it is violence. In fact, modern 'pedagogy' operating in various institutions from schools to prisons apparently endeavours to limit the use of physical violence, while the instruments of symbolic violence are becoming ever more sophisticated and refined. The role of, and the interplay between, these two forms of violence may perhaps help also to understand some characteristics of the modern totalitarian states, and some of the differences between its Nazi and Bolshevik variants.

And lastly, the suggestion of Elias quoted in the motto has to be taken seriously. The process of civilisation is a process of 'longue durée'. Several generations may be needed to make the process of 'absorption' through socialisation effective. However, the process is not necessarily cumulative and continuous in one direction (unilinear) ${ }^{9}$. The onset of a new decivilising process cannot be excluded on the level of (some) nation-states, or on the global level. Its impact may be felt even if it does not go the whole way. It may start with those elements crumbling first which were last to be built up, without the necessary time to become consolidated. Obviously, in crisis situations outside forms may be the first to be shed - in an air-raid shelter one does not dress up for dinner. But if conditions are changing so that physical survival is threatened, the 'super-ego' may also crumble. (It is not an extreme example that with disproportionately increasing energy prices many formerly 'honest' families start to steal electricity.) It is a likely hypothesis that the deeper the roots of the super-ego, the more difficult it is to 'get rid' of it. This may render 'overcivilised' people defenceless in the face of such phenomena of de-civilisation as, for instance, the increase of the level of open violence. Another, interrelated likelihood is that those will be the first victims of decivilisation who had been the last ones reached by the civilising process.

In short, civilisation is understood here as a historical process assisting and promoting social coexistence within continuously changing complex modern

\footnotetext{
${ }^{8}$ The debates about the death penalty form an interesting case illustrating this point.

${ }^{9}$ There is a new body of research centered on the decivilising processes which I cannot handle here in depth (Duclos 1993, Fletcher 1995, 1997, Mennel 1990).
} 
societies. The process may have been more or less violent; it has always been socially structured; and it is historically reversible.

\section{Processes influencing 'modern' civilisation.}

All established societies have had a civilisation, but these have differed depending on economic, political and other conditions. In the last centuries there evolved processes which conditioned the 'modern' civilising process in particular ways. Out of them I shall mention only three. They influenced not only the contents of what is meant by modern civilisation as an ideal, but also the activity of the agents involved in spreading it, and the outcome of their operation. A crucial element in this story is the changing role of the state.

\section{Increasing social density and complexity}

One relevant and (from Durkheim to de Swaan) often analysed thread is the increasing density in many realms of society in the last centuries, and hence the increasing complexity of social relations. These developments are connected through various feedback mechanisms to the evolution of the capitalist economy, to growing productivity, the improving availability of goods over spreading geographic areas, and the perfection of technologies in many areas of life.

Population growth followed as mortality rates dropped and life expectancy lengthened. The story is familiar. Still, we rarely meditate about the significance of some of the figures involved. Let us just have a look on Europe. What can it signify that the number of its residents grew -- albeit in an uneven way because of losses due to wars, migration, epidemics-- from 40 to 150 million between 1000 and 1800, and then to 270 million in 1850, and 530 million in 1950? The density may be particularly strongly felt in towns. The ratio of those living in towns over hundred thousand grew, between 1850 and 1980, for instance in France from 5 to $28 \%$, in Denmark from 9 to 38\%, in England from 2 to 71\%, and even in Hungary from 1 to 29\% (Handbuch, vol.4:56; vol.5:12,42; vol.6: $12.18,54)$. How can so many people live side by side?

Meanwhile, the increasing differentiation and specialisation in all fields (the emerging 'organic solidarity' in Durkheim's theory) required the multiplication of more or less autonomous institutions and organisations. The growing complexity of market relations gave rise to a network of ever more dense contractual relations as well as of lengthening networks of communication, based on roads, transport, the media. The process is still continuing in our days when the trajectories of movement on the earth and in the air slowly fill up the space, and the mass of electronic information cram in the ether. The growing number of people had become interrelated by relationships of a widening variety. The situation thus created has been described by historical sociology as 'the extension and intensification of the 
"chains of human interdependence" in the course of time, as the "generalisation of interdependency"' (Swaan, 1988: 2.) What concerns us here is that as the number of the relationships with others and the types of the contacts have been multiplying, the likelihood of frictions, of spontaneous or deliberate disturbances affecting these networks, and of damages caused thereby, has been steadily increasing. The threat represented by these disturbances to normal social coexistence, or to civilisation in the above sense is easy to grasp.

\section{Differentiation and exclusion - The dangerous and endangered poor}

Another aspect of this history is the changing social nature of poverty. The historical, structural, socio-psychological and causal questions of poverty since the earliest times and particularly since the Middle Ages, as well as the relationships and societal responses to the challenges of poverty are treated by many eminent scholars on various - parish, country, European, or even global - levels. (For instance Castel 1995; Gans 1996; Geremek 1987; Mollat 1987; de Swaan 1988.) No summing up is intended here: I just pick some elements fitting my purpose.

With increasing social density and mobility the 'untouchable, ${ }^{10}$ had become visible. In the growing cities they could become close neighbours. Their visibility may have been already uncomfortable for the 'established' whose sensibility had increased with the Enlightenment (Mollat 1987). In fact, the life of these endangered poor was much more exposed than that of the betteroff in two senses. They were more exposed to all forms of physical sufferings, and to the public eye. The ills affecting them had become visible for instant through hungry street urchins, murdered 'illegitimate' infants (Chevalier 1958), homeless beggars, emaciated women. These sights affected the new sensibilities. The real trouble was, however, that the poor have become more dangerous than heretofore. They may have represented direct personal danger through the threat of robbing or committing crimes for subsistence. Or the danger may have been more indirect, when the poor were seen as a group representing or exuding physical and moral 'evils' ${ }^{11}$.

Because of all these facts, it became a must not only to take notice of the existence of these 'others', but also to do something in more organised ways than traditional charity did. When - with increasing density and geographic mobility - the poor had become 'strangers', traditional alms-giving became difficult because of the free-rider problem mentioned by Swaan. (Others may profit from the appeasement obtained at my expense.) Also when the former

\footnotetext{
${ }^{10}$ The expression ' untouchable' is an appropriate metaphor here: it conveys the combination of social and physical distance.

${ }^{11}$ Swaan describes convincingly how and why cholera may be considered as the paradigm of urban interdependence (Swaan 1988, Chapter 4.2).
} 
hierarchical relationships of bondage or spontaneous submission were transformed into more horizontal connections, and the respect of (individual) human dignity has become an accepted value, the patriarchal forms of almsgiving had become - at least theoretically - more controversial.

The emergence of the working class resulted in new forms of misery and conflict as compared to the 'pre-industrial' poor. The workers' status was affected by new insecurities. The dangers of grave accidents, of job losses, of unprovided old age all increased. The family as the traditional helping agent was less available not only because of increased geographic distances, or smaller families, but also because the relatives of the urban workers were also without means. (In the towns one could not even fall back on subsistence agricultural production.) The problem was uncertainty in the immediate present as well as in the future. The dangerous character of working class poverty was amply increased by the propensity and ability of workers to organise. Individualised solutions to these problems were unattainable to those concerned, and even the traditional organisations of mutual help failed to respond to the new needs essentially because of the scarcity of resources.

Increased competitiveness, growing individualism and the weakening of traditional moral authorities

The dilemmas related to competitiveness when it becomes morally approved selfishness, and is seen as the driving force of market success, had been discussed by many scholars since Kropotkin's book on 'Mutual Aid' (for example, Tawney 1931; Rotenberg 1977). The relationship between secularisation and modernisation has also often been on the agenda since Max Weber's work on the issue. From my perspective it would be important to find the connections between all three of the above trends. This task is not yet completed, thus only hypotheses can be formulated. The assumption is, by and large, that market-conform behaviours compel individual solutions, but many social problems such as those mentioned above are difficult or impossible to handle by individual means. The moral authority of religion, or any similar institution of traditional authority that could have harnessed market-conform egoism has waned away. Thus new means had to be found to reconcile strengthening individualism with the increasing need of intervention in matters concerning the public.

The historically evolving answer had been, of course, the increasing role of the central authority, of the state to which we soon turn. But there are open questions which will be ignored hereafter. We do not know under what conditions, if any, may the state acquire morally compelling authority in handling the conflict between individualism and social troubles not manageable by individual means. We do not know, either, what may be the consequences of the weakening of moral imperatives if these conditions do not materialise, particularly under the conditions of globalisation. 


\section{Answers to the above challenges - the increasing role of the state}

Increasing density, complexity, inequality and poverty within the frameworks of the unfolding market economy represented challenges to society.

Obviously, social coexistence and the reproduction of societies was seldom, if ever 'unregulated', but the regulatory institutions and mechanisms underwent considerable change through time. To take only Europe, the power of the head of the household over the members, or the "lord" over his "subjects" was usually sufficient to regulate the coexistence of the relatively small and relatively isolated communities throughout the Middle Ages. In the localities - in villages, parishes, towns -- instances of "corporate power" had emerged. But as the chains of human interdependencies lengthened and multiplied, so occurred an upward shift in the power centres assuming regulatory roles.

In the Middle Ages there were relatively few problems requiring central regulation. I have gathered the impression that the first function which became centralised and had almost continuously remained through history at the top power level was coinage, implying the guarantee of the value of coins (New British Encyclopaedia, vol. 2:333). Of course there always had been contenders (lords were often prone to coin their own money). However, the conflicts over the monopoly of coinage seem to have been relatively mild and usually transitory. It gives indeed food for thought how widely accepted had this state function become, and how seldom was it questioned even when the overall role of the state has been under heavy attack. It also shows an extraordinary trust in the state that (except in unusually turbulent times) everybody, anarchists included, use and accept valueless pieces of metal or scraps of paper at their nominal value if the state is assumed to guarantee the value.

How other matters have become gradually more 'public', more centralised depended on the outcome of the struggles between 'centralising and decentralising forces’ (Elias 1982). The decentralising forces led for instance to the multiplication of autonomous states in Europe, while centralising tendencies within a given area, usually the emerging states appeared as a result of the fights of the parallel powers, that is the princes or kings, the lords, the church, the towns, or sometimes various oligarchies. These struggles ended with a -- more often temporary than lasting -- truce at different times. The open struggles between the church and the prince around the right to promulgate binding laws reached a turning point for instance at the Investiture Controversy. It is after the journey to Canossa that the Church (the Pope) has recognised the authority of the king in worldly matters (Badie 1987), albeit the contents and the boarders of the authority have continued to be debated practically up to our days.

The monopoly of using legitimate violence in case of internal and external conflicts (probably the most often mentioned and the best recognised state 
responsibility nowadays ${ }^{12}$ ) as well as that of tax collection was the stake of incessant struggles for centuries between the same actors. If we tend to define the state in our days just by the monopoly of violence and that of taxation, this may mean that their appropriation marks the demarcation line between the pre-modern and the modern state.

Literacy and numeracy had become increasingly important in these matters as well as in the spreading 'contractual culture'. Church monopoly in educational matters was slowly overcome because of overall social changes. But there was strong and lasting opposition against giving better education to the lower classes (for fear of losing cheap labour, for fear of new abilities to question the status quo, and so forth). Nevertheless, the operation of an increasingly complex economy, the spread of bureaucracy and the wish of strengthening the nation state required the transmission and the inculcation of common norms and codes. It followed from the nature of the need that basic education had to become public responsibility, and had to be publicly funded at least in case of the poor.

Public health and social housing follow a similar pattern. The need for them may be illustrated by the changes in urban public health arrangements. The lack of clean running water, of refuse collection and of sewage made it impossible to ward off contagion. Individual solutions for some of these amenities could have been financed by the rich, but this would not have helped, if the open gutter remained there. And their collective action was paralysed (as shown by Swaan) by the free-rider problem. Thus the responsibility was shifted this time, too, to the town, and ultimately to the state which was able to collect taxes and could build up the institutions of public hygiene. It has to be emphasised that this activity could be effective only if it encompassed whole communities.

The changing economy presented yet other problems. The self-regulating market, as it unfolded, seemed to take care some of the chaos, and this belief is still alive. However -- as many historians have shown (from Polanyi on) -- the smooth operation of the so-called self-regulating markets has always necessitated a considerable amount of outside (state) regulation and legislation. Indeed, each and every sub-field of economic life - from the protection of property and 'fair competition' to the regulation of traffic, or labour relations, or the quality control of goods for the protection of the consumers - has its own history of unfolding (state) regulation for the sake of the 'public good' (Hill 1976).

Industrialisation changed also the nature of pre-industrial poverty. Conditions prevailing in factories as well as the new risks of income loss connected with the workers' status has triggered waves of unrest and anxiety. The

\footnotetext{
${ }^{12}$ It may well be true, though, that 'any state that failed to put considerable effort into war making was likely to disappear' (Tilly 1985:184).
} 
involvement of the state in handling the new risks and reducing the mounting unrest and anxiety was a necessity this time, too. It may have included strengthening control and repression, but also 'remedial' actions, including Factory Acts, labour market regulations, and new forms of income support. All of them involved public action. The two early systems devised for handling the risks of the new conditions have become, or proved to be, inadequate: mutual help associations set up by the workers themselves did not work well because of the lack of sufficient funds (Hatzfeld 1971, Swaan 1988, for Hungary Petrák 1978); and commercial insurance which served quite well the better-off was unattainable for the majority either because of the lack of funds, or because of the failures of the insurance market (recently spelt out by Barr, 1987, Burchardt 1997). The forms state involvement has taken from the last third of the 19th century is a much studied topic of social history both on the national and the international level (for instance Baldwin 1990, Flora et al, 1971, Rimlinger 1974). It could take the form of social insurance 'invented' by Bismarck or of means-tested, and then (near)universal provisions as was the case in Anglo-Saxon and Scandinavian countries. With the additional impetus of the First World War, and then of the World Crisis, the main risks -accidents, death and widowhood, sickness, maternity, unemployment -- had been covered in most European countries at the eve of, or soon after the second World War at least for workers.

Considering the nature of the early social functions of the state, it may be conjectured that the standards of the institutions and benefits thus created had to be relatively inferior. It is hard to discover strong social interests which would have militated for decent (and not minimal) levels of social assistance, or for high standard public hospitals. Even without adequate documentation, social logic suggests that high-standard institutions serving only the poor or the workers had to be extremely scarce. And whenever we find them, it is almost certain that their existence will be due to the efforts of a strongly motivated and generous philanthropist, or to a particularly progressive civil movement.

Slowly, however, the above institutions have spread to the whole of society. The collectivisation of welfare or, in other words, the unfolding of national solidarities is really the story of the welfare state after the second world war (albeit in some countries, particularly in Scandinavia, the process started earlier). This latter period is not devoid of clashes of interests, of struggles and conflicts, either (Baldwin 1990). The motives for the later development may have been mixed. Solidarities forged during the war, the memories of collective sufferings, new progressive ideas may have played a role as well as the challenge of the eastern 'socialist' bloc, the interests of a growing state bureaucracy, or the self-interest of the middle-classes who wanted to benefit also from their own taxes.

Countries of course differ as for the speed or scope of the developments, the standards achieved. But about a decade after World War Two 'collective, 
nation-wide and compulsory arrangements' had been developed over Western Europe ‘to cope with inefficiencies and adversities' (Swaan 1988:.2 and Conclusion), and also to promote such objectives as the reduction of social inequalities in physical and social life chances, or to enhance social justice (whatever this means) and the sense of citizenship. These arrangements helped to adjust people to the increasingly complex world, and restricted or corrected to some extent the market logic. In the modern welfare state good-quality kindergartens, public hospitals, decent pensions ceased to be rarities. Good quality social insurance combined the market logic and individual self-interest (the ‘value for money' requirement) and the moral imperative helping coexistence. Even social assistance had acquired -- occasionally at least -forms compatible with human dignity. When their quality improved, the collective arrangements could become or could appear as less discriminatory, less enforced, or less punitive. Hence, they could become more effective in their 'civilising functions'. With the help of all these institutions western societies had become somewhat better (at least according to my value scale). Poverty did not disappear, but its scope and depth were reduced. The poor had become less endangered, less dangerous, and suffered probably less. The gap between life chances was reduced in many walks of life, for instance the difference between the length of life allowed to the rich and to the poor, or to the children of rich and poor. Also out of the many anxieties and insecurities afflicting human existence some -- those at least which could be reduced to a calculable status -- could be alleviated.

This is not the end of the story, though. The legitimacy of state monopolies could not be "eternalised". Each of them has been questioned or attacked at turn by various social actors. Out of them, the market forces have become recently increasingly vigorous contenders in the provision and distribution of goods and services which had become collectivised. The controversies around the monopolies of nation-states are visibly growing in intensity with the process of globalisation. 'The dominant position of markets may be due to the fact that no supranational authority has the power to discipline transnational markets which increasingly threaten the sovereignty of nations. .. With governments politically unable to rise above the national interest, the market wins '(Boyer and Drache:7). The parties involved now in these struggles include the nation-states, supranational agencies and the new international oligarchy.

It is a different matter to what extent did all these processes take place in Central-Eastern Europe with which I propose to deal in a different paper. The main (preliminary) conclusions of this analysis may be briefly summed up for Central-Eastern Europe, and may not fully apply to Eastern Europe. The fissure between the West and the rest of Europe and that between CentralEastern and Eastern Europe - starting in the Middle Ages (Szücs 1983) impacted on the modernising and civilising processes up to the 20th century. Despite deliberate and repeated efforts of 'adjustment' less has trickled down and went less deep. The collective and compulsory institutions of integration 
started to evolve relatively early for instance in Hungary, but the system expanded much more slowly. It was only under dictatorial state socialism that the compulsory and collective arrangements promoting 'modern civilisation', or creating conditions for its unfolding, attained to cover the whole of society ${ }^{13}$. The totalitarian systems, particularly at their early stages, certainly had momentous de-civilising features and impacts. Nonetheless, the so-called 'premature' welfare state, and even the new ideology produced gains. I think the most positive outcome of 'socialist dictatorship' is the reduction of the civilisation gap both between east and west, and between the higher and lower echelons of society. Many civilising acquisitions spread through society, even if the very bottom may have been hardly touched. I believe that the chances of those countries to adjust to the requirements of political democracy and a market society, or to conform to the expectations of the European Union which they want to join, would be currently much worse without the 'premature' welfare arrangements.

\section{Civilisation as a complex syndrome}

The explicit and implicit, overt or covert civilising impacts of the school system, the health system, the social insurance schemes have been analysed by many. I want to focus here on some possible impacts of social security in the large sense. Social security in general, social insurance in particular, even if compulsory, are instruments which give a sort of guarantee to be able to cope with future adversities or difficulties. These arrangements represent the compulsory institutionalisation of the ability of rational foresight (of deferring gratification if you wish), an ability which is socially very unequally diffused. This means that one is enabled to reckon with the future without too much particular individual effort. In this sense, the impact of these arrangements resembles that of the public monopoly of violence. Social security schemes reduce the necessity of being constantly on the alert for fear of (socially manageable) adversities in the same way the monopoly of violence frees the citizen from the constant obligation of preparing individually for unexpected attacks.

Facing the future means of course more than saving (in one way or another) for old age or sickness. It involves the whole problem of social reproduction, particularly the preparation of the children for life, including their schooling. Of course, one never gains mastery over the future. However, when there are all-encompassing collective arrangements of social security, including those helping the children to prepare themselves for life, this increases one's autonomy over one's life-course. It may even motivate action. Let us assume that I may be confident that my child will be able to continue its studies in line with its interests and abilities, and that schooling will enable it to get ahead in life. Under these conditions it makes sense to encourage the child to

\footnotetext{
${ }^{13}$ It is an ahistorical, albeit interesting question how this same process would have evolved if the Yalta decision about the partition of Europe had been different.
} 
work well at school. (Empirical findings for Hungary suggest that the availability of free schooling spread the habit even among uneducated and badly off parents to think about the future of their children as different and better than their own[Ferge 1969]).

A farther, and in my mind a socially and psychologically crucial effect of social security is the reduction of the level of omnipresent anxieties, at least of those which may be socially manageable uncertainties. The social significance of anxiety and insecurity seems to attract ever more attention (Ferge 1996, Kraemer et al, 1997, Marris 1996). Psychologists may be right in assuming that the feeling of security is crucial. In Freud's terms, security is the absence of anxiety. A child cannot rid itself of its more elemental anxieties and it cannot develop properly if it lacks the mother, or at least a permanent, security-giving care-provider stepping in her place. We can feel anxious over the threats of nature; over the health or life of our loved ones (or of ourselves); over the stability of our relations with people; over risks of losing much of what we have; over the opportunity to secure our everyday bread by keeping our job; to be able to pay the next bill or the medication for our child or parents (Ferge 1996).

Some of those may be termed essential anxieties having to do with our biological, mortal nature, with our affections, or with our psychological dispositions. These anxieties seem to belong to the human condition itself, and cannot be 'abolished' without losing our humanness. Others may be seen as existential anxieties, stemming from social conditions. Both are, though, in Freud's terms, real anxieties, that is, not pathological or neurotic symptoms, and it is always painful to experience them. 'The kind of situation in which anxiety arises naturally largely depends on the degree of our knowledge, and on how powerful we consider ourselves in relation to the outside world.' Realistic anxiety is, however - Freud continues - neither rational nor expedient because 'it paralyses all action...'. It would be expedient, rather, 'to size up coolly one's own strengths in comparison with the magnitude of the threat, and then to decide whether to escape or defend ourselves, or perhaps an attack itself would provide more chance for everything to end well' (Freud, 1986:321, from Hungarian).

The human condition has always been fraught with sources of anxiety. We know indeed very little how much the medieval man may have suffered from them. Maybe a lot, if we recall superstitions and ghosts, demons and the various frightening representations of purgatory and hell (Le Goff 1988). Maybe little. Perhaps in absence of the means to create defences, the only way of a 'normal' existence was to ignore the incalculable dangers and the uncertainties of the unknown. As a consequence, it may have become possible to accept without complaint and fear the acts of God, including natural calamities and man-made disasters, afflictions and death. And perhaps one could trust to get compensation in the next world. 
More close to us, we know also next to nothing how much the poor suffered of anxiety from sickness and old age before the appearance of the collective pension and health schemes. I suggest, though, that once the instruments of managing certain risks have emerged and have become accessible, the former situation changes. We become then conscious of these risks as constituent elements of insecurity even if this was not the case earlier. Again, there is a parallel with reliance on the police and legal redress instead of dealing individually with aggressive attacks. Once available, the instruments of risk management become important: if the access to these instruments is itself unsure, this causes anxiety and may become paralysing. This pattern also is part of the civilisation process -- be it a blessing or a curse.

This conviction explains why I cannot share the negative assessment of many economists and politicians about social security when they affirm that social security has spoilt people. According to them risk aversion has become a general trait that is a character failure. This defect should allegedly be corrected, and each individual should become responsible for his/her present and future ${ }^{14}$.

If we accept the historically hardly contestable idea of a civilising process, then we should see it as a whole. We have to realise that it has affected both our superficial behaviours and our more deeply ingrained habits. Most of us living in complex modern (European?) societies have learned to use regularly soap and towel. This has become our 'second nature' -- at least as long as we have running water. It has also become our 'second nature' that (under normal circumstances) we keep as a matter of course the terms of a market contract, or that we seldom feel the urge to steal unattended goods in a supermarket. Meanwhile, we have also 'learned' through a long historical process to take it for granted that running water is normally available and affordable, as well as medical care or the school attendance of our children. We can often act more efficiently as autonomous individuals if our energies are freed from the fear of attacks or from elementary existential threats. I believe that these processes and the traits they produced cling together. The 'syndrome' of civilisation may be very different in societies with dissimilar conditions and histories. Also, it varies within a given society depending on the operation of the civilising process, on who was reached and how. But it seems to be a syndrome. I think therefore that it is a psychological and historical error to qualify some of the elements of the syndrome the 'inherent traits of a civilised person' and some others as defects of character.

\footnotetext{
${ }^{14}$ Interestingly enough, they never go as far as to propose to people to build up their own defences against individual violent attacks. If this is spontaneously happening in case of the rich, this is just a sign that there is a syndrome: the weakening of some elements may have repercussions on others.
} 


\section{And what if the state retrenches - West and East}

One could gather the impression from the previous arguments that the civilising process -- at least in the West -- was cumulative and followed a direct line. This is clearly not the case. Even though it is only a footnote in the manuscript of Elias written in the thirties, he explicitly suggests what was presented as one of the mottoes, namely that

The armour of civilised conduct would crumble very rapidly if, through a change in society, the degree of insecurity that existed earlier were to break in upon us again, and if danger became as incalculable as it once was. Corresponding fears would burst the limits set to them today. (1939, I.: 307)

Revolutions, wars, grave natural or social calamities and crises, then in an unprecedented way Fascism and Bolshevism all entailed various anti-civilised and de-civilising effects. The onset of a new decivilising process cannot be excluded on the level of (some) nation-states, or on the global level.

Civilisations have collapsed before. The idea of the 'end of civilisation' is put into inverted commas here. Still, the dangers of 'decivilisation' loom large. They seem to affect first those lastly reached. However, they appear to impact also on those who reject both all moral authorities and the enforced authority of the state.

We have argued that out of the many historic processes of capitalist development three had been particularly instrumental in propelling the growth of the welfare functions of the state. We have mentioned increasing density and longer chains of interdependence; the multiplication and the visibility of the dangerous and endangered poor; and the consequences of the simultaneous strengthening of selfish individualism and the decline of moral authorities. Apparently, none of these tendencies have subsided. The contrary would be more true.

Let us focus on the most compulsive problem, that of the poor. In the last one or two decades new factors have contributed to the expansion of poverty. Among them we find growing unemployment, the destabilisation of jobs, declining earnings, increasing income and wealth inequalities ${ }^{15}$. They all may have contributed to the accentuation of such problems as homelessness, hopelessness, criminality, other forms of deviant behaviours. As a consequence, tendencies of social disintegration, marginalisation, or exclusion, sometimes the appearance of an 'underclass' have become parts of the social scene. The number of those who are useless either as producers or as

\footnotetext{
${ }^{15}$ Martin and Schumann have calculated that in the coming years the rate of unemployment could increase from 9.7 to $21 \%$ in Germany, from 7.3 to 18\% in Austria. Together with all the other changes on the job-market, they project a 20:80 society, with 20 per cent in a good position, the others losing out (1996:146-147.)
} 
consumers, who 'are a useless weight on the earth' ${ }^{, 16}$ (Castel 1995) is increasing.

Similar phenomena prompted the state 150 years ago to complete its policing functions with welfare functions. The state took action in the first place for the sake of the well-to-do and 'social peace'. Its action was also needed to shape a more 'civilised' labour force. The improvement of the conditions of the poor made them more fit as producers. Later on, they have become important also as consumers.

We currently witness the institutionalised weakening of the collective, allencompassing and compulsory arrangements. There is a growing literature analysing the -- real and alleged -- reasons for trimming the welfare state (for instance Esping-Andersen 1996, George and Taylor-Gooby 1996). The first direct consequence of the cuts is the downgrading of the institutions: either their coverage may shrivel, or their standards may decrease, or both. Their attractiveness is weakening, together with the alleged readiness of people to pay taxes for deteriorating services. As the other chapters in this volume show, data substantiate the contrary: in most European countries, East and West, people are willing to pay even more taxes for good or better collective services.

If the situation is similar to what it used to be 150 years ago, but the reaction is different, this has to mean that the groups who felt themselves threatened and forced the state to obtain quiescence through improving the lot of the poor feel less threatened now. The reasons are diverse, and cannot be discussed here in detail. One element stands out, though, namely, that the state is expected to change its profile. Its monopoly of violence is questioned in the name of the freedom of self-defence. This freedom is restricted, though, to the rich. For the others, the policing functions of the state have to be strengthened ${ }^{17}$. In fact, public safety remains important also for the better-off. Thus they press the state to strengthen its regulatory and punitive role against those who endanger their bodily safety and their property (Jordan 1996:212-221). In all probability, the current revolt against redistribution does not really want to weaken the state. It just wants to change the balance between its oppressive and enabling functions. The state is meant less to serve the 'Safety of People' in general than that of those who have the most to lose and to fear.

We have argued that the process whereby the policing functions were completed and then partly replaced by welfare functions was instrumental in 'spreading civilisation' and making societies more liveable. If this is true, then the reversal of this process may trigger a process of decivilisation or anticivilisation -- even if the other processes, particularly increasing density and

\footnotetext{
${ }^{16}$ The quotation is from an 'édit' of Charles IX from 1566 quoted in Castel 1995.

${ }^{17}$ The increase of the prison population particularly in the US is well known. The rules of social assistance tend to become harsher, enforced workfare is often replacing 'welfare'. The problem of minorities, migrants and refugees also often unleashes police violence.
} 
longer chains of interdependence among those who are insiders in the chains are not going backwards. The logic above suggests, though, that the process may not affect everybody - 'only' the 30 or 50 per cent who 'sunt pundus inutilae terrae', the dead weight.

The consequences of the waning away of elements of civilisation in some parts of society are easy to think through (logically if not morally). If conditions change so as to make scarce knife and fork, inside toilet, hot water, then water itself (Huby 1995) as well as space for privacy, then habits tied to them have to change. All these changes, including the lowering of the level of shame ${ }^{18}$ and the weakening of many other self-restraints set in with tragic rapidity in case of the homeless. But the non-poor may become involved, too. If the institutions of social security in general are weakening, the habits developed in relation to money, to time, to space, to self, to others are all jeopardised (as shown for instance by the case of stolen electricity). More generally, the quality of society as a whole may be affected by these developments. This is particularly true if we accept the definition of social quality as recently proposed by a group of European scholars. They suggest that social quality rests on the degree of economic security, the level of social inclusion, of solidarity, and of autonomy or empowerment (Beck et al, 1997:3). All of these bases are eroded with the 'decivilising process' described above.

The scenario is not rejoicing. And it may not be in line with what we like to think about 'European civilisation'.

\section{References}

Ariès, P. et G. Duby, eds. (1987) Histoire de la vie privée. Paris: Seuil

Badie, B. (1987) 'La pensée politique vers la fin du XVIe siècle: héritage antique et médiéval'. In: Ory, P. (sous la direction de) (1987) Nouvelle histoire des idées politiques, Paris: Pluriel..

Baldwin, P. (1990) The politics of Social Solidarity. Class Bases of the European Welfare State 1875-1975. Cambridge, New York: Cambridge University Press

Barr, N. (1987) The Economics of the Welfare State. London: Weidenfeld and Nicholson

\footnotetext{
${ }^{18}$ Do we ever realise what does it mean for a formerly 'civilised' homeless in terms of physical suffering and a psychological demeaning experience to have no place to excrete?
} 
Beck, W., L. van der Maesen, A. Walker (1997) The Social Quality of Europe. The Hague-London-Boston: Kluwer Law International.

Bourdieu, P. (1972) Esquisse d'une théorie de la pratique. Genève: Droz

Bourdieu, P. and L. J.D. Wacquant (1992) An Invitation to Reflective Sociology. Chicago: The University of Chicago Press.

Boyer, R. and D. Drache (1996) States Against Markets. The limits of globalization. London and New York: Routledge

Burchardt, Tania ( 1997) What Price Security? Assessing private insurance for long-term care, income replacement during incapacity, and unemployment for mortgagors. Suntory and Toyota International Centres for Economics and Related Disciplines. London School of Economics. WSP/129.

Castel, R. (1995) Les métamorphoses de la question sociale. Une chronique du salariat. Paris: Fayard

Chevalier, L. (1958) Classes laborieuses et classes dangereuses à Paris pendant la première moitié du XIX siècle. Paris: Plon, 1958.

The Columbia Encyclopedia, Fifth edition, 1995, Houghton Mifflin

Duclos, D. (1993) De la civilité. Comment les sociétés apprivoisent la puissance. Paris: Éditions de la découverte

Elias, N. The civilizing process, vol I. The history of manners, 1939 (1969, 1978); vol II. State Formation and Civilisation (1982) Oxford/New York:Blackwell

Elias, N. and J. L. Scotson (1994) The Established and the Outsiders. London, Thousand Oaks, New Delhi: Sage.

Esping-Andersen, G. (ed.) (1996) Welfare States in Transition. National Adaptations in Global Economies. London - Thousand Oaks-New Delhi: Sage.

Ferge, Zs. (1969) Társadalmunk rétegezõdése (Social stratification). Budapest, Közgazdasági és Jogi Könyvkiadó.

Ferge, Zs. (1996) Freedom and Security. International Review of Comparative Public Policy, vol.7. 1996.

Fletcher, J. (1995) Towards a Theory of Decivilizing Processes. Amsterdams sociologisch Tijdschrift, jrg.22. nr.2. oktober 1995. pp. 283297 
Fletcher, Jonathan (1997) Violence and Civilization. An Introduction to the Work of Norbert Elias. Cambridge: Polity Press.

Flora, P. and A. Heidenheimer, eds. (1981)The development of Welfare States in Europe and America, Transaction Books,

Freud, S.(1951) Civilisation and its discontents. London: Hogarth Press

Freud, S. (1986). Bevezetés a pszichoanalízisbe. (Introduction to psychoanalysis) Gondolat, Budapest.

Gans, Herbert J.(1995) The War Against the Poor. The Underclass and Antipoverty Policy. Basic Books (A Division of Harper Collins Publishers)

George, V. and P. Taylor-Gooby (1996) European Welfare Policy. Squaring the Welfare Circle. Macmillan Press Ltd; Houndmill and London.

Geremek, B. (1987) La potence et la pitié. L'Europe et les pauvres du moyen age à nos jours. Paris: Gallimard

Handbuch der Europaischen Wirtschafts-und Sozialgeschichte, több kötet. Stuttgart: Klett-Cotta (several years of publication)

Hatzfeld, H.: Du paupérisme à la Sécurité Sociale. Paris: Librairie Armand Colin, 1971.

Hill, Michael (1976) The State, Administration and the Individual Glasgow: Fontana/Collins

Huby, M. (1995) Water Poverty and Social Policy: A review of issues for research. Journal of Social Policy, April 1995.

Jordan, B. 1996. A Theory of Poverty and Social Exclusion. Cambridge: Polity Press, 1996

Kalb, D. (in press, 1997) Expanding Class: Power and everyday politics in industrial communities, North Brabant illustrations, Ca. 1850-1950. Durham and London: Duke University Press

Kraemer, S. and J. R., eds. (1997) The Politics of Attachment. Towards a Secure Society. London: Free Association of Books

Kropotkin, Peter (first: 1902, 1955) Mutual Aid: A Factor of Evolution. Boston: Extending Horizons.

Le Goff, J. (1985) L’imaginaire médiéval. Paris: Éditions Gallimard

Martin, H. P, Schumann, H. (1996) Die Globalisierungsfalle. Der Angriff auf Demokratie und Wohlstand. Rowohlt Verlag 
Marris, P. (1996) The Politics of Uncertainty. London and New York: Routledge.

Mennell, S, 1990. Decivilising Processes: Theoretical Significance and Some Lines of Research. International Sociology, vol.5. no. 2. pp.205-223

Mollat, M.(1978) Les pauvres au Moyen Age. Paris : Hachette

(The) New Encyclopaedia Britannica

Petrák K. (1978) A szervezett munkásság küzdelme a korszerû társadalombiztosításért. Budapest:Táncsics

Rimlinger, G. V. (1974). Welfare Policy, Industrialization in Europe, America and Russia. New York: John Wiley

Rotenberg, M. (1977): "Alienating-individualism" and "reciprocal individualism": a cross-cultural conceptualization. Journal of Humanistic Psychology, Vol. 17., no.3. Summer 1977

Soros, G. (1997) The Capitalist Threat. Atlantic Monthly, January 1997.

Swaan, A. de (1988) In Care of the State: Health Care, Education and Welfare in Europe and the USA in the Modern Era. New York: Polity Press/Oxford University Press (Page numbering is based on the multigraphied edition of Amsterdam University of 1987)

Swaan, A. de (1990) The Management of Normality. Critical essays in Health and Welfare. London and New York: Routledge

Szûcs, Jenõ (1983) Die drei historischen Regionen Europas. Frankfurt: Verlag Neue Kritik

Tawney, R.H. (1964) Equality London: Unwin Books. (First ed. 1931.)

Tilly, C. (1985) "War Making and State Making as Organized Crime” In Evans, P., D. Rueschenmeyer and T. Skocpol (eds.) 1985. Bringing the State Back In. Cambridge: Cambridge University Press 